\title{
4日資料 I0
}

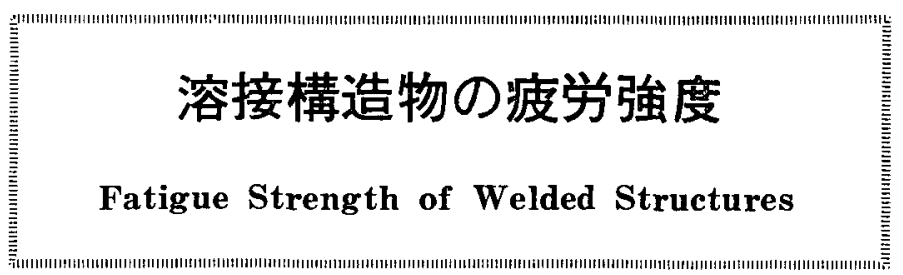

\section{溶 接 鋼構 造の疲労 設 計理 念*}

白石隆義**

Fatigue Design Concepts of Welded Steel Structures*

by Takayoshi Shiraishi**

\section{1. 累積との戦い}

大気污染, 水質污濁, 海洋污染, P.C.B., 力ドミュム，有機水銀などといった公害問題は，今日人類の生存 に最も大きい脅威を与えようとしている，そして人類は これらの公害との戦いにおいて一進一退を続けるのみで 決定的勝利を得るには至っていない．

科学の発達した今日よ゙うして一挙に勝利を収めるとと ができないのであろうか.

それは，とれらあるいはこれらによる被害がすべて累 積現象であるためである。すなわち一つ一つはほ之んど 無害と思われる事象が，数多く繰返されるうちに，その 累積によって一つ一つの場合には想像もできなかったよ うな結果をあたらすからである。

したがって，「現代は累積との戦いの時代である」と いうことができる，そして今や人類は一人一人が累稫と の戦いの場に臨んでいるととを認識しなければならな い.

しかしながら工学の世界ではすでに一世紀以上す前か ら累積現象之の戦いが始まっている。すなう方疲労，磨 耗および腐蝕との戦いである，そして，他の方面での輝 かしい戦果にひきかえて，てれらとの戦いでは，最近に なってようやくなんとか有効な戦略戦術を編み出すてと ができるようになったにすぎない。

本資料は乙れらのうちの繰返し荷重をうける鋼構造物

*原稿受付 昭和47年12月 7 日

**正 貝 (侏)ダイレ Member, Daikure Co.,
の涭労付対して設計者たち，とりわけ設計基準の作成者 たちが採用してきた，そして今後探用するであ万う戦略 戦術とその理由のあらましを述べようとするものであ る.

\section{2. 疲労設計理念の歴史}

\section{1 安全率}

一般的にいって構造物の設計は，計画した使用期間の 間損傷することなく要求される機能を発揮し続け，しか 李綜合的にみて最も経斎的な構造物を追求して進められ る.

したがって強度だけ沉ついてみれば，損傷が起らない 必要最小幔の強度にいくらかの余裕があればよいのであ って, それ以上の不必要な強度の余裕は不経済であると いうことになる，安全率とは，実際に棈造物に与えられ る強度とこの必要最小限の強度との比と考えるのが最も 罗当であろう。

ところが荷重が繰返し作用する構造物では前述の累積 現象がからんでいるために，この必要最小限の強度の把 握がむつかしく，安全率つ意味が久しい間愦って考えら れてきだ、.

歴史的な経過をざっと眺めてみよう、まず19世紀の始 めまでは木材，石材，鋳鉄などの曲げあるいは引張を受 ける部材に用いるには全く不適当な材料を用いて構造物 が作られていた．材料自身の中にしばしば大小の欠陷が あり，しかむよ゙のような欠宿が存在するかを検查する適 当な力法がなかったので，欠陷がない場合には恐るしく 
無䭾だと思われる楽面が用いられていた，それにもかか わらず時おり，大小の損稘が発生していた。すなわち奏 際の安全率には非常に大きいばらつきがあった.

当時発生した鍀鉄構造物の損傷の中には欠陥より発し た疲労による損傷がかなりあったのではないかと思われ るが，䤣鉄のような脆い材料では微小な疲労き裂を生ず るとあ己は一挙に脆性破濖を起すために延性材料の場合 のような疲労破面が認められず, 静的破燷による破面之 区別できないため，すべての損傷は静的強度の不足によ り起ったものと考えられていた。

19世紀に入って構造技術者待望の靬性に富んだ練鉄が 登場し，続いて軟鋼が出現する。乙れらに至って材料の 蚛度上のばらつきは非常に小さくなり，材料の内部欠陮 に帰因する損偍は絶滅した。 そして，トラブルのほとん どは当時材料の結合に専ら用いられていた鋲継手のゆる みやきれつであっていずれも致命的なものではなかっ た.

しかしどくまれと架設中あるいは最大荷重時に大き な破壊が発生した。

この大きな破壊事故はほとんどの場合設計者の計算 : スまたは予测ミスあるいは工事の際の過失に㷌因する屯 のであったが，すべて王縮材の座屈が誘因となってい た. 研究のために行われた静荷重による模形あるいは実 物の破壊試験ですすべて破壊は座屈により扢った。この ため各種の座屈の研少が進められ，多くの設計基準（仕 方書）は正縮材の計算上の安全率を㣂心その他の影響を 考虑して1.5〜2.0亡するのが普通となった。

一方，鉷継手に対してはどのような安全率がこられて いたであろうか. 繰返し荷電をうける構造物の引張をう ける镔継手に打ける材料の純断面当りの許容㤁力として は總䜬の場合 7 8 $\mathrm{kg} / \mathrm{mm}^{2}$ 歌鍽の場合 $12 \sim 13 \mathrm{~kg} / \mathrm{mm}^{2}$ が長い閣採用されてきた。

単純に考えると練鉄あるいは軟鋼の符的な最低の引張 渱さはそれぞれおよそ30あるいは $40 \mathrm{~kg} / \mathrm{mm}^{2}$ であるか ら，安全率は4あるいは3程度であるということにな る。または降伏点を基準にすると妧全率は 2.5 あるいは 2ということになる.ところがこのような考え方は実際

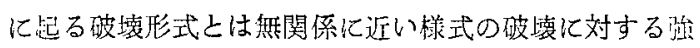
度を安全率つ基準に上っているから非常に危险な教方方 ということになる。

上記の許容応力は，乙れらの応力が繰返し作用した場 合にトラブルが起らない(換言すれれば疲労による損傷が 起らない)てとを目標にあまり余裕なしに定められたも のである2).

鋲継手のトラブルは鋲により締めつけられた隣接する 二板の板の間に过りが起り，と执繰返されると起るの
である、したがって継手の設計が不適当であったり，鋲 の締付け力が不十分であったりすれば上記の許容応力の 繰返しであトラブルは起りうるのである.すなわち安全 率は許容灾力住しい片振り応力が繰返し作用する場合 にはいくらか1.0より大であって，時には1.0以下になる こともありうるのである.

しかし, この許容応力は最大応力に対する值であった ため, 死荷重応力があって応力変動䇛团が小さい場合に はそれに応じて安全率は 1.0 より大きくなり，また設計 時に想定した最大荷重が常に作用するのでなければ，さ らに安全率は大きくなってゆく.

このような理由で嵞構造物に打ける実際の安全率は引 張正縮いずれにおいてす 1.0 よりかなり大きく，そのた めあまりりラブルが起らなかった。

やがて，軟鋼よりも強い材料として高張力鋼が出現す る.この材料でも鋲継手の疲労強度はあまり向上しない のであるが, 平穞無事が続くうちに，いつのまにか人々 の心のうちに浸透していた前記の単純な考え方，すなわ ち「許容応力は引張強さ（あるいは降伏点）を安全率 3.0（あるいは2.0）で割った值である」という考え方が 受け継がれ, 高張力鋼の引張に対する許容灾力は引張り 強さ（あるいは降伏点）に比例して高められるに至っ た．幸いにして高張力鋼は死荷重応力の大きい，また大 きい荷重の繰返数の少い構造物に多く用いられたため軟 鎆を用いた場合大きすぎた安全率が適当に小さくなった だけで，トラブルがあまり起らないという結果となっ た.

20世紀のなかばに接溶が出現し，急速にそれまでの鋲 構造が溶接棈造に移り変った. 始めは䟬を単純に溶接に おきかえた構造が用いられたが，次第汇溶揁の長所を生 かした設計が行われるようになった。

初期の溶接構造物の没計では鋲時代の基準をそのまま 踏䪭して母材の引張りに対する許容応力として一律に鋲 継手に対する值を用いていた，そして，溶接部（溶着金 属) には必ず欠陥があるものとして，それに対する許容 応力を若低目に定めていた。

しかしながら，繰返し荷重在うける溶接構造物に生ず るトラブルはほとんどが瘦労によるあのであることが明 らかとなりままた备種の溶接継手の瘏労試験データが蓄 積されるにつれて, 溶菇継手の種類によって疲労强度に 著るしい差があることが認識され，溶接構造における許 容応力体系はこれらのデータを基榃にして改められるに 至った。

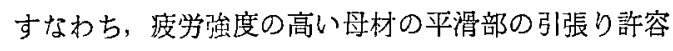
応力は敘継手に対して定められた值 $\left(12 \sim 13 \mathrm{~kg} / \mathrm{mm}^{2}\right)$ から次第に高い值に改められ，反面高い応力集中のため 
鋲継手よりあ大巾に鋲労強度が低くなっている溶接継手 に対しては許容応力が低く定められている。

しかしながら鋲構造時代に行われていた最大荷重によ る応力がその作用する繰返数とは無関係化許容応力を超 えなければよいとする方式が踏襲され，でく最近になっ てようやく荷重の䪽度分布の影響すなわち累積の影響を 考慮してより合理的な設計をしようとする思想が表われ るようになった．また高張力鋼の溶接部の疲労強度が乾 鍋に傚べてほとんどすぐれていないととが明らかになる につれて，絽返し荷重をうける高張力鋼溶接継手の汻容 応力は次第に軟銅のそれに近づけられている。

以上を要するに練鉄時代よりこのかた，でく最近まで は繰返し荷重をうける構造物の引張部材は, 設計最大応 力を最大值とする片振り引張応力が十分多く繰返し作用 した場合の安全率がおよそ 1.0 となるように設計されて きたのであり，実際の安全率は，死荷重応力の占める割 合が大きい程, そして大きい荷重の繰返し作用する頻度 が小さい程大きくなり，また反面，高張力鋼なるが故に 軟鋼より高い許容応力が与えられた場合や，応力集中が 著るしく，採用した許容応力に較べて実際の波労溞度が 低い場合には小さくなるといえる。

\section{2 仕方書における疲労没計条項の変遷}

設計の際に疲労を考虑しなければならない鋼構造物の 中で最も古くから仕方書が定められていたすのは鋼鉄道 橋である。

したがって疲労設計理念の歷史的変遷をたどるには鐥 鉄道橋の設計仕方書に盛られた怶労設計条項の移り变り を調べるのが最もよいと思われる。

先ず1091年に米国鉄道技䢹 T. Cooper 驾作った仕方 書を挙げるのが適当であるう. Cooper はこの仕方書に
よりクーパー荷重なる鉄道橋用の近代的荷重体系を制 定しているが，繰返し荷重の問題に関しては，活荷重が 通過するうちに応力の䈆号変化が起る部材に対し（交番 応力), 正負の各応力に小さい方の応力の $1 / 2$ を算術的に 加えた值が許容応力を超えないてとを要求しているに過 ぎない，そしてての種の条項は Cooper 以前の仕方書に あ認められる。

わが国においては明治45年（1912年）に始めて鋼鉄道 橋設計仕方書が制定され，昭和 3 年 (1928年) 飞その改 訂が行なわれているが，乙れらはいずれす外国の仕方書 を参考に作られたむのであり，その疲労設計条項は全く Cooper の仕方書と同一であった.

てのようにして溶接が鉄道橋に本格的に用いられるよ うになるまでの半世紀余りの間は鉄道橋の設計仕方書に はこれ以外の波労条項は表われなかった。

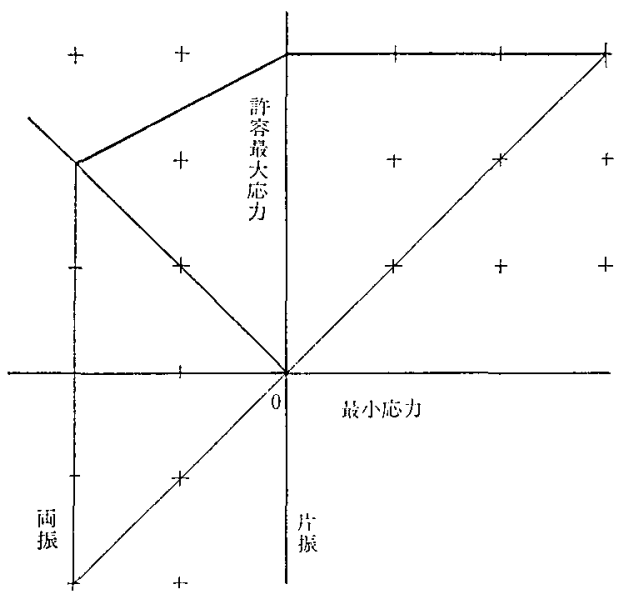

図 1 初期の訢容㤁力

玨一1 最近の各国設計化方曺の疲労条項比較

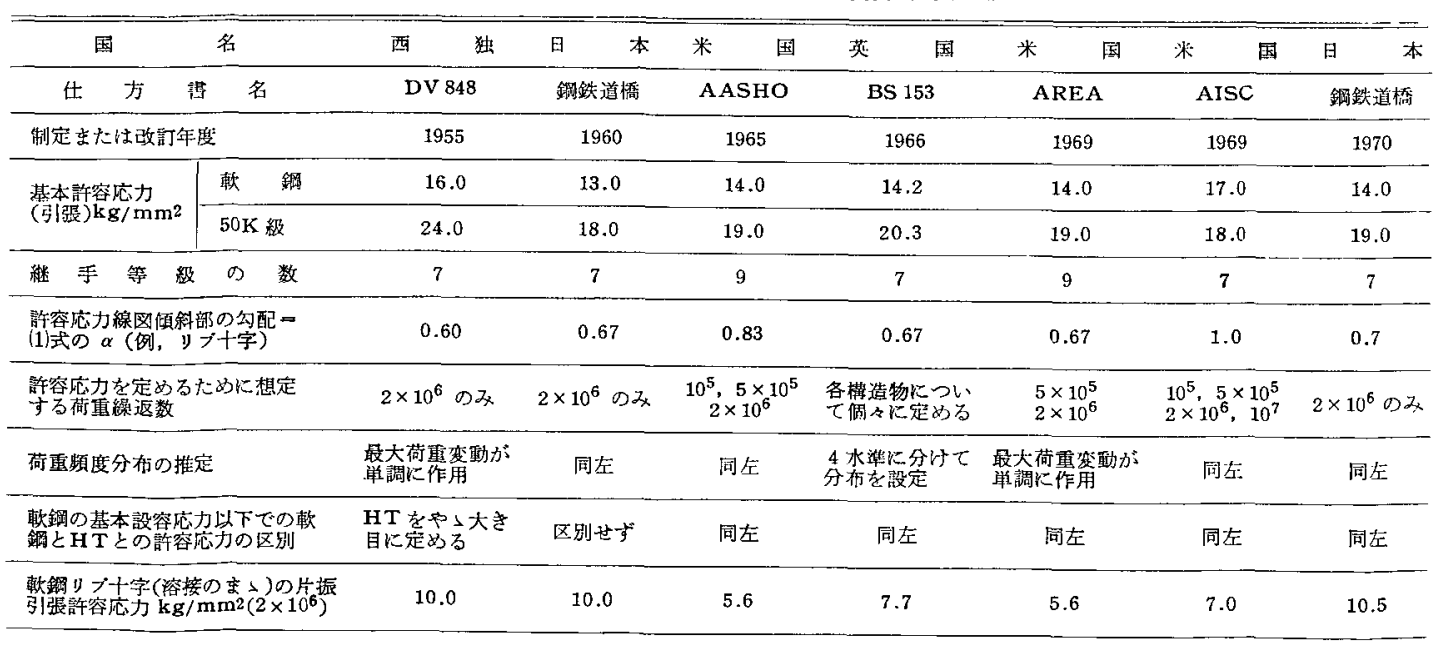


乙の条項の要求する許容応力 $S_{\mathrm{a} 11}$ (最大応力) を最小 応力 $S_{\min }$ を横軸にして表わすと図 1 のでとくなる．そ して図 1 の許容応力線図の傾斜部を最大応力と最小応力 との此 $k$ を用いて表わすと（1）式において

$$
S_{\mathrm{a} 11}=S_{0 a} /(1-\alpha k)
$$

$\alpha=1 / 2$ とねくことになる. ことに $S_{0 a}$ は $k=0$ すなわ ち片振りの場合の許容応力である.

20世紀の後半に入り, 溶接継手の疲労に関する知識が 整うにつれて，それまで鉣構造時代の思想をほとんどそ のまま受けついで暫定的に定められていた鉄道橋の設計 仕方書にとれらの知識を反映させる動きが各国に㧍いて 起り，次々之新しい仕方書が制定され改訂されている。 その動きのあらましを追うために，日本（国鉄），米国 (AREA)，英国（BS153）および西独（OV 848）の鋼鉄 道橋設計仕方書，ならびに参考のために米国の AASHO および AISC の仕方書の疲労条項の主な内容を比較す ると表 1 のよおりである.

すなわち，母材の基本許容応力（引張）の欄では軟鋼 に対する值が日本や米国で次第に高くなり，早くから高 く定めている西独に近づく傾向を示している.

各種の継手は $7 \sim 9$ の等級に分類されている.

一例としてあげたリブ十字に対する強度線図の傾斜部

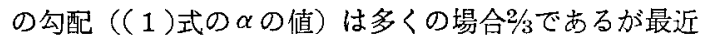
は 1.0 にする場合がでてきている。乙れは後にも述べる ように溶接の残留応力の影響などを考えて平均応力の影 響を軽視し，応力範囲のみを重視しようとする方向に向 っていることを示す.

想定する荷重の繰返数および頻度分布については，日 独では単に一定の最大荷重が $2 \times 10^{6}$ 回作用することを 想定しているが，米国では構造物や部材の種類により 2 $\sim 4$ 種類の絽返数を考え, 最大荷重がこの繰返数だけ作 用するてとを想定しており, 英国の BS 153 では, 構造 物や部材の種類によって，それぞれ異る荷重の繰返数わ よび頻度分布を想定している. このため BS 153 では各 等級の溶接継手倿対する $S-N$ 線図（表）を与え，累䅡 疲労被害を計算することを求めている。

西独の DV848 を除き軟鋼の基本許容応力以下では軟

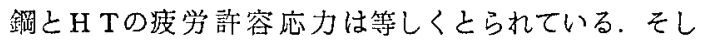
て，一例としてあげた溶接のままの㴓泠によりスチフナ を付けた母材 (リブ十字) の棓容応力 (片振引張)は日 独が比較的高く英米之次第に低くとられている．T.R. Gurney は各種の溶接継手に対する各国の設计仕方書に 示された瘏労許容応力を比較して，国によりかなり大き い差があることを指摘し，共同研究その他の方法を用い て万国共通な䛧を定めるべきだと述べている32.
各種溶接継手の疲労強度に関するデータを各国が協力 して整借するてとについては大いに賛成であるが，仕方 書に示された許容応力の差は必ずしも疲労強度データの 差によるものではないかむしれない，というのは，仕方 書の許容応力は, これらのデータの他に荷重の大きさゃ 頻度分布に関する規定と実䟢との相違などあ若虑に入れ て定められているからである。したがって, 表 1 の場合 必ずしも日独のデータが高く，英米のそれが低いと断定 するわけにはいかない。

\section{3. 疲労設計（基準制定）に際 し考慮すへきき諸問題}

\section{1 合理化と簡単化の調和}

設計仕方書などの設計基準は，それに従って設計製作 された構造物が綜合的にみて最も経済的で（単に製作費 や機能だけでなく，安全性す万一損傷が起った場合の経 済的, 社会的損失の期待值として考虑に入れる)，しか も設計作業がなるべく簡単であることが望ましい．すな わち合理化簡単化の相矛盾する要素をうまく調和させ ねばならない。

疲労設計においてての調和を得るためには，疲労の諸 因子の中で重大な影響ありと考えられる因子は，できる だけ正確に反映し，さほど重大でないと判断されるもの はできるだけ簡単化の方向に向って考虑するといった配 虑が必要である，以下各種の波労の諸因子について，そ れぞれよ゙のように判断すべきかについて述べる。

\section{2 荷重つ繰返数之頻度分布}

最む重要でありながら推定が非常にむずかしいため， これまでの設計仕方曺のほとんどが澼けて通ってきた問 題である。しかし，今後合理化を追求するならば，ての 問題に敢然と立向わねばならない，

同種の構造物に関するなるべく正確な資料を集め，ば らつきを考えてやや安全側飞推定するのが適当である う. この場合, 頻度の捕え方が重要であって, 計測その 他の便宜のために本質を見失うようなととがあってはな らない.

疲労き裂発生の最も重要な条件が，そ性ひずみの絽返 しであるから，途中の荷重（応力）の増隇には無関保に 大きい荷重 (伈力) 変動範囲から順に正確に計数するレ ンジペア法を用いて頻度分布を測定するか，あるいは， この精神で推定しなけ机ばならない1，レンジペア法の 弱点は計数法がややむずかしいととと, 平均応力とは無

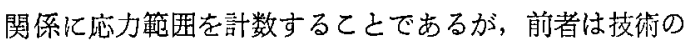
進歩につれて克服されるであ万うし，後者は後に述べる ように平均応力の影響はあまり大きくないと考えられる から，それほど問題にしなくてよかろう。 
最近になって，この荷重頻度分布の問題と取組んだ研 究が多〈進的られている4)5\}677

\section{3 波労強度のばらつきと $\boldsymbol{S}-\boldsymbol{N}$ 線図}

溶接継手に一定の応力変動 (最大值, 最小値, 平均值

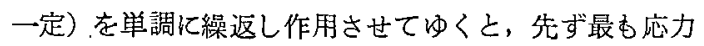
(ひずみ）集中のきびしい筒所の表面よりわずか内に入 った位置微小き裂を生じ，てれがやがて拡大して表面 に表われ，さらに拡がり続けて全断面が破壊するに至 る.

普通の場合内部溦小き裂を生じた時期を知ることは できないので，き裂が表面に表われて観密された時点を き裂発生とし，それまでの応力繰返数をき裂発生までの 絽返数 $\left(N_{c}\right)$ とよぶ. そして，き裂が進行して，はじめ の応力変動条件が維持できなくなった時点までの繰返数 を破壊までの繰返数 $\left(N_{f}\right)$ とよぶ，すなわち $N_{f}$ はき 裂発生に要した繰返数 $N_{c}$ とき裂進展任要した繰返数の 和である。

$N_{c} / N_{f}$ の比は，切欠が鋭く応力集中率が大きいほよ゙， また疲労限を超えて応力が大きくなるほよ゙小さくなり， 時には1/10より小さくなることああるといわれている.

これまでの多くの疲労試験では $N_{f}$ だけしか求められ ず, 試験結果は応力変動量 $S$ と $N_{f}$ との関保を両対数 紙にプロットして表示されている．との場合各データの 点は普通一つの曲線（あるいは直線）上に乘るととはな く,かなりのばらつきを示す.

機械加工により応力集中の条件を揃えた人工切久試験 片を用いた疲労試験の結果であある程度のばらつきを示 すが，溶接継手の場合には全く同じ溶接条件に上る溶接
でも場所により応力集中の程度が異るため，疲労試験結 果はかなりばらつき，同じ継手を異った人や異った条件 で溶接した場合には結果のばらつきはさらに大きくな る。

そして，このばらつきは波労強度の高いすなわち応力 集中率が小さい溶接継手活よ゙大きい傾向がある.

普通，てのようなばらつきの平均値を通るような曲線 （直線）を画いててれを $S-N\left(S-N_{f}\right)$ 線図（図2)之 呼んでいるが，設計用のデータとしてての $S-N$ 線図だ けを用いるのは適当でない，なぜならばての $S-N$ 線図 よりどの程度まで低い強度の溶接継手が存在するかわか らないからである．換言すればばらつきに関する情報 が含まれていないからである。

現在のよころ，とのばらつきを考えて，ほとんどのデ 一タはこれ以上であるという下限線の意味で，破壊確率 $1 / 200$ 信頼限界線（乙れを破買確率 $5 \%$ D P $-S-N$ 線図 之呼ぶ）求め，乙れをその溶接継手の強度データとし て用いる方法がよいとされている19910).

前述のように， $S-N$ 線図（あるいは $P-S-N$ 線図）を 画くための繰返数 $N$ としては, 普通 $N_{f}$ が用いられて いる.

実際の構造物においては，進行性のき裂が発見されて もまだ破壊までには多くの時間がかかるであろうから といって，そのまま使用が続行されることはなく，必ず 補修および多くの場合補強が講ぜられるから，てれらの 補修や補強による経済的損失を考えれば，軽量化が構造 設計の第一条件であるといわれる航空機などの婸合を除 き，設計は寿命期間中に疲労き裂を発生させないととを

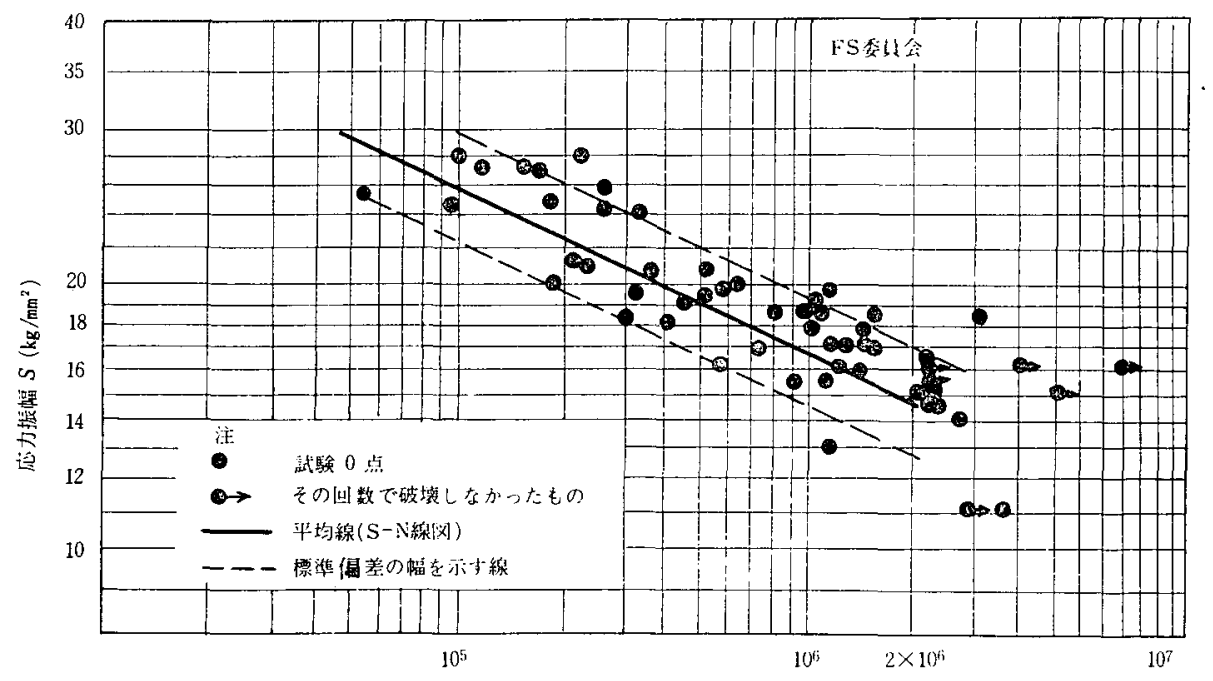

䄉这し数 $N$

図 2 軟䤱突合せ継手（非仕上，無欠陌）の片振引張疲労試験結果のばらつき 
目標に進められるべきである，したがって，Nf のかわ りに $N_{c}$ を用いた $S-N$ 線図が設計上は必要である：さ らに後述するように，累䅡疫労被書の問題はき裂発生だ けに限って考えないと混乱を生ずるという見地からも， $S-N_{c}$ 線図が必要となる。

現在は $S-N_{c}$ 線図（ばらつきを考えた破壊確率 $5 \%$ に 対する $P-S-N_{c}$ 線図を含めて）は全く求められていな いから，既存の各種のデータにもとずいて，なる心゙く正 碓でやや安全側と思われる線図を推定しなければならな W(図3).

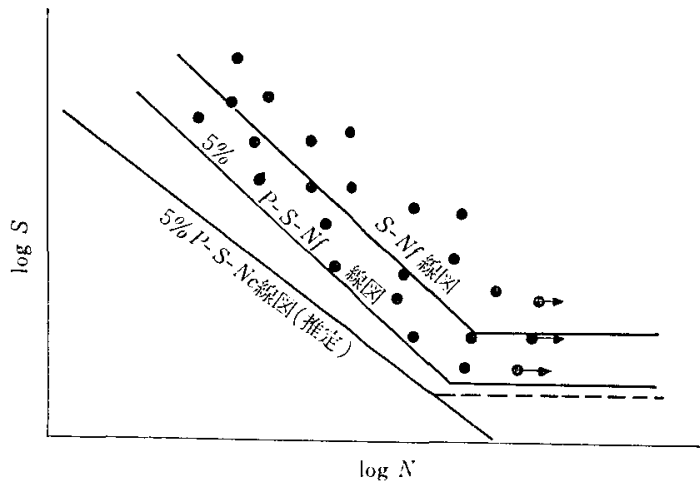

図 $3 \quad P-S-N_{f}$, および $P-S-N_{c}$ 線図（推定）

\section{4 平均応力}

一定の心力変動 $\left\{\right.$ その最大值を最大心力 $S_{\max }$, 最小 值を最小応力 $S_{\min },\left(S_{\max }+S_{\min }\right) / 2$ を平均応力 $S_{\text {mean }},\left(S_{\max }-S_{\min }\right)$ を応力範围 $S_{r}, S_{r} / 2$ を応力振 巾 $S_{\mathrm{amp}}, S_{\min } / S_{\max }$ を応力比 $k$ と呼ぶ\}を繰返し加 えて破壞（き裂が発生）するまでの繰返数 $N_{f}\left(N_{c}\right)$ を 求める病労試験では，普通 $S_{\text {mean }}, S_{\min }$ あるいは $k$ の いずれか一つを一定にし，S，を試験片ごとに変化させ て，その結果により $S-N$ 線図を画き，乙れより疲労限 や，時間強度を求めるのであるが， $S_{\text {mean（あるいは }}$ $S_{\min }$ や $k$ ) が変った場合のこれらの強度は溶接継手の 場合，実際によ゙のように変るであろうか.

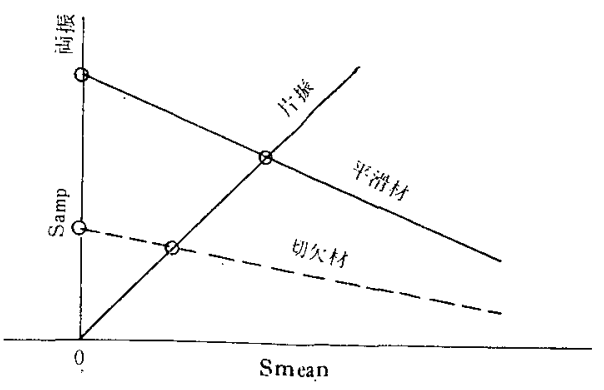

图 4 疲労強度線図
，平滑材の場合は $S_{\text {mean }}$ と $S_{\text {amp }}$ との間に図4 の奏線 のように $S_{\text {mean }}$ が0より大きくなるにつれて $S_{\text {amp }}$ が 直線的に減少する傾问があるとされてきた。（疲労強度 線図)

切欠材の場合にも $S_{\text {mean }}$ の増加につれて $S_{\mathrm{amp}}$ は減 少するが，その度合は平滑材の場合に較べて，劫力集中 の度合が大きく，疲労強度が低いほざ小さい己いわれて きた. (図 4 の点線)

溶接継手の舅合屯切欠材の場合と，ほぼ同じ傾向を示 すといわれてきた。

しかしながら，これらの強度線図は多くの場合， $S_{\text {mean }}=0$ の両振のデータと, $S_{\min }=0$ の片振のデータ だけによって画かれるととが多く, 平均応力が白っと大 きくなった場合のデータが整った場合にもやはりとれま でに画かれた通りの直線関係が保たれるかどうが疑問 である。

それだけでなく，二，三のデータは否定的な傾向を示 し応力集中が大きく瘦労強度が低い場合には， $S_{\text {mean }}$ が 片掁以上では，平均応力の影響は図 50 ようにかなり小 さい上考えられる。

このことは，応力集中が大きい場合には，平均応力が 変化しても，応力集中部での応力とひずみの関係は，疲 労試験の初期の段階におこるそ性変形により，ほぼ同じ

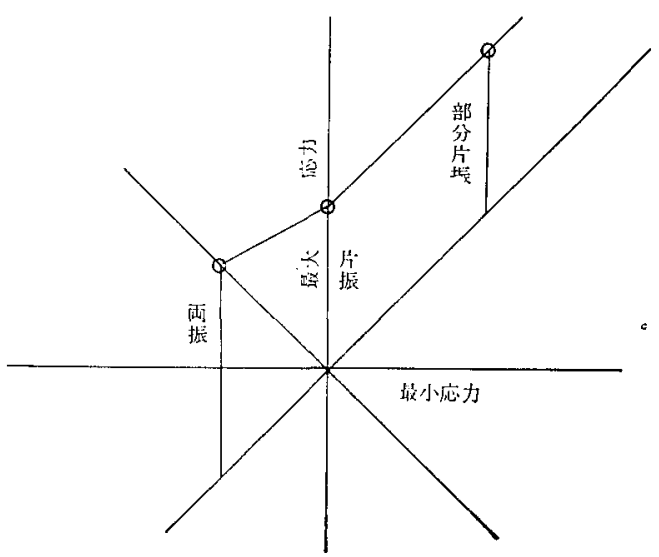

図 5 平均応力の影響

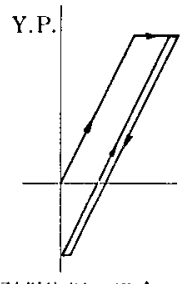

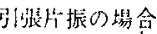

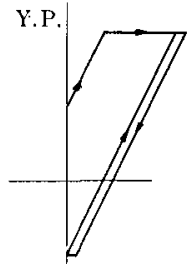

部分施张版振の場合

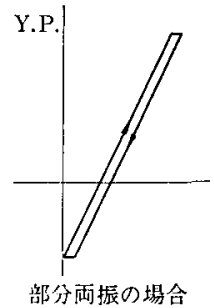

部分両振の場合
図 6 応力集中部における応力とひずみの関係 
になるであろうことから，定性的に推祭することができ る。（図6）

また，平均応力が片振りの場合より小さくなり，压縮

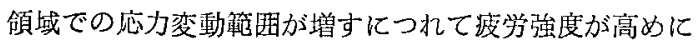
表われる（四 5) ことについては，次のように説明する ことができる。

すなわち, 平均応力が減少して压継領域での応力变動 籁囲が増加しても，試験途中の応力とひずみの関係は， き裂が発生するまでは，ほぼ同じと考えられるから，き 裂発生までの絽返数はほぼ同じであ万う(図6).しか しながら，一旦き裂が発生してからのき裂の進展速度

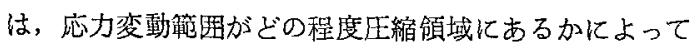
著るしく変化し，てのため片振の疲労強度上り両振のそ れが，やや大き目に表われるのである゙、。

したがって，もしすべての疲労試験結果がき裂発生ま での絽返数で整理されるようになれば, 平均灾力の影響 は，応力集中が大きい場合すべての範囲において，あま り重要でなくなるであるうと思わ机る。

このように，平均応力の影響が，そ机程重要でないと いうことは, 溶接構造物の波労設計においては, きわわ て有利なことである，というのは溶接構造物には溶接熱 により，大なり小なりの䇝留応力が生じており，てのた めに, 実際作用する応力变動の平均応力は, 外加加 える荷重变動から算出されるそれとは全く買っており， 設計時に残留応力による平均応力の移動を推定すること は不可能であるから, 平均応力の影響が万一重要であっ てむ，てれを考虑するととはできないからである。

しかし，一たん疲労き裂が発生した後のき裂進展化対

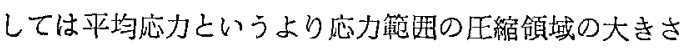
の影響はかなり大きい，そして，き裂進展過程全般につ いては, 構造物の内部で釣合っている残留応力の影響 は, マクロにみて一応無視できるとすれば, 荷重による 応力変動範囲の圧縮領域の大きさは，き裂発生後の寿命 が長くなるという意周で, 設計時に考虑されるべきであ ろう.

\section{5 疲労被害の累棈}

一般の構造物では海回ランダムに変化する応力変動を うけるのが普通であるが，かかる棈造物の部材や継手の 疲労寿命を, 一定の応力变動に上る疲労試験結果を用い て推定するためには，疲労被害の罳積という概念を導入 する必要がある.

最す簡単化考兑られる概念としては，ある大きさ（お よび平均応力）の応力变動による疲労被害は過去の応力 履歴には無関係比一定であるという仮定から帰納される 直線累積被害則（いわゆるマイナー則）である．との直 線累皘被害則化よれば， $S_{1}, S_{2} \cdots S_{i} \cdots$ なる応力变動が順
芧は無関係にそれぞれ $n_{1}, n_{2} \cdots n_{i} \cdots$ 回ずつ作用したとき の疲労被害 $D$ は，(2) 式で与兄られ，D=1 亿なる之 き裂発坐 (破璮) が起るのである。

$$
D=\sum n_{i} / N_{i}
$$

ここに， $N_{i}$ は $S_{i}$ が単調に作用した場合のき裂発生（破 壊）までの絽返数である.

これまでに，乙の直線累積被害則が罗当であるか否か を険証するための多くの実験が遂行された，そのなかで 最屯多く行われた，始めに $S_{1}$ を連続して $n_{i}$ 回作用さ せ，続いて $S_{2}$ を繰返し作用させて破壊させる二段荷重 の波労試験の結果の多くはやや否定的で, $D$ は順序に より大きくむ小さくむなっている.

ここで十分注意しなけ机ばならないことは，疲労き破 が一たん発生した後は直線累積被害則の前提である波労 被害が過去の履歷に無関係という仮定が明らかに成立た なくなることである.

ところが，すでに这べたように，てれまでの疲労試験 では $N_{f}$ だけしか求められないため，(2) 式の $n_{i}$ や $N_{i}$ にむき裂発生後のき裂進展偠する繰返数が含まれ ており，破壞時の $D$ が1よりあ大巾に大きくなったり 小さくなったりした理由の第一はてのへんにあるのでは ないかと考えられる。

あち万ん，て礼以外の理由もいろいる指摘されている が，笅密汇き裂発生をとらえた実験により，ての法則の 罗当性が明ら汃化されるまでは，乙れ以外提案されて いる各種の疫労被害則は䶂単化の要請に反する幔り，仕 方書つ中に盛込まれないであろうと考えられる。

前述の上うに累積被害則はき裂発生だけに限って適用 されねばならないが，き裂発生後破壊までの寿命も万一 き裂が発生した場合の構造物の安全性の見地から設計時 に若虑されるのが望ましい。

たとえば，き裂発生には何等の貢献をしない低い応力 の繰返しも，一旦き裂が発生した後にはき裂進庋に貢献 するであろうから，かかる波労限よりやや小さい応力の 繰返数が非常に多い構造物と, そうでない構造物とで は，き裂発生に対する安全率に若干の相違があってしか るべきであろう。

この配虑を簡単に設計に織込むには，設計に使用した $S-N_{c}$ 線图が嗦労限（かりに存在が確認されたとして） で水平に折曲っていても，乙れを折曲るとせず满労限 以下もそれ以上の傾向が持続され $N$ の增加につれて $S$ が低くなると仮定して設計を進めればよい，(応力集中 が大きい場合の $S-N_{f}$ 線図は， $N_{f}$ の大部分がき裂進展 に要する繰返数であるため, き裂の進展速度の傾向に大 きく影響されて，勾配が急になっている，むし疲労限以 
下の応力のき裂進展に対する貢献を考虑に入れるため， ての急な勾配をそのまま延長して，䍗積被害を訢算する と不当に安全側になりすぎることになる，)

\section{4. 今後の疲労設計理念}

今後新たに制定または改訂されるであろう設計仕方畫 (設計基準)に盛り込まれる疲学設計理念は前章に記し た諸問題に関する最新の知識を織込んで，合理化と簡単 化の調和を計ったものとなるであるう.そして，その大 要を予想すると次のとおりである。

(1) 涛命期間中に疲労き裂が発生しないととを設計 の目標とする。

（2）き裂発生だけに対し直線罢樍被害則を用いる.

（3）各種継手に対する $P-S-N_{c}$ 線図をできるだけ 正確に推定しててれを用いる.

（4）軟鎡亡高張力鋼亡は疲労強度に関しては差がな いとして敢报う。

（5）平均応力の影響はき裂発生に対しては無視でき るとする。

（6）応力の頻度分布を棈造物の部材や継手ごとにな るべく正確に推定しててれを用いる．乙の推定の場 合，レンジペア法の精神で頻度分布の計数を行う.

（7）き裂発生に対する安全率は応力計算が精密に行 なわれるようになった場合には $5 \%$ 破罗確率の $P-S-N_{c}$ 線図が用いられるがり1.05〜1.250範围 で棈造物の重要性や軽量化への要求の强さに従って 探用される。

（8）き裂発生後の等命の長短が安全率に加味され る.すなわち，疲労限以下の応力の繰返数が非常に 多い場合には安全率はやや大き目に，また応力変動 籍围の圧縮領域にある部分が大きい場合には安全率 はやや小さ目によられる.

現在，日本鋼構造協会技術委員会耐久性分科会の中の 疲労小委員会は，上記の線にそった波労設計指鉊の原案 を作成中である11).

この原案の中で特に目新らしいことは, 各種継手に対 する $P-S-N_{c}$ 線图をいずれ屯两対数紙上で同じ勾配 $(K$ $=-0.18)$ を持つ直線であると仮定し，さらに5\%破壊 確率の $P-S-N_{f}$ 線図の $N_{f}=2 \times 10^{6}$ 回の強度が $N_{c}=$ $10^{6}$ 回の強度であると仮定しているととである.そして 一応，との直線は疲労限なしに無限に下ると仮定してい る.

\section{5. 今後期待される研究}

以上を読まれてもおわかりのように，合理的でしかも 簡単な疲労設計基準を打立てるためには，現在であ不明
な点が多過ぎるといえる，これら不明な点を解明するた わの数多くの研究が今後期待されるのであるが，その主 なあのを気が付くままに記すと次の通りである。

(1) 疲労き裂発生の機楎の解明

この研究はおそらく非常に困難であろうが，むし解 明された場合には平均応力や累積被害の問題も明確 になるであろう。

（2）各種継手に対する $P-S-N_{c}$ 線图の確立

てのためにはき裂の発生と進展の移り変りを明らか にしなければならない。

（3）各種構造物における荷重の頻度分布に関するデ 一夕の集皘

レンジペア法で数えなりればならない必然性の証明 あ同時泌必要であ万う。

(4) 直線累積被害則の適用可能範囲の把握

（5）平均応力の影響の解明

（6）高張力鋼の溶接継手の疲労強度が軟鋼のそれに 較べて優れていない原因の解明

（7）構造上の応力集中部江疲労強度の低い継手が存 在する場合の強度低下の度合の解明

一方研究とは別に疲労による溶接構造物の損傷防止の ために声を大にして叫びたい問題がある。それは構造物 の設計や製作㑺わる人々，および将来携わるであるう 人々に対する教育の問題である，波労によるトラブルが 構造物のトラブルの大半を占めて捛り，てれらトラブル の原因の大半が設計者や製作者の疲労比関する知識の欠 除化あるいう点からいって，教育の重要性は明白であ る.

\section{6.あとがき}

以上述べた溶接構造物の疲労設計に関する考え方の大 部分は, 10 年余任亘る F S 委員会（溶接学会疲労強度研 究委員会)での勉強を通じて筆者の頭の中に形成された あのであって，その中に有益な部分があれば，それは $\mathrm{F}$ $\mathrm{S}$ 委員会の功績であり，愦りがあったとすれば，それは 筆者の考えが浅薄であったととに帰せられるであるう。

ここ江文末を借りて F S 委員会の委員各位偣対する敬 意を謝意を表明する次第である。

\section{参考 文 献}

1）白石：「溶接技街者のための度学の知祴」，溶接技街，1969年 7 月〜 11 月

2) J.G. Whiteman; 「The Problem of Cumulative Damage in Welded Structures, 1970 Welding Institute Conference on "Fatigue of Welded Structures" 冹料

3) T.R. Gurney; 「A Comparison of Fatigue Design Rules $\lrcorner, 1970$ Welding Institute Conference on "Fatigue of Welded Structures" 筫料

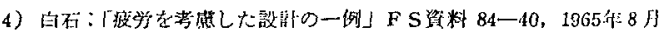


5）伊藤：「实颠荷重に上る铁道橋の疲当被害推定」，鉄研報告No. 676,1969 年 4 月

6）国広，井上：「道路橋の疲学設計」，道路、1972年 3 月，FS資料一 275-47, 1972年

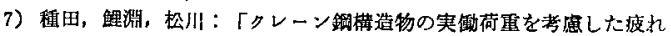
強さについて，F S 资料214-45，1970年 4 月

8）白石, 吉田：「大形鉄道連絡船の強度ならびに啃造設咭に関する研
犯，跌研報告 No. 816 1972年8月

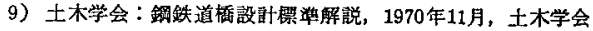

10）白石：溶接設計者のための披芀関する一般常識，溶接技獄，1964 年 1 月 5 月

11）白石：疲当設計指針案の考え方について，FS盗料258一-46，1971年 6 月

\title{
疲労強度から見た溶接継手の分類*
}

\author{
太田省三 郎** \\ Classification of Welded Joints from a Standpoint \\ of Fatigue Strength*
}

by Shozaburo Ohta**

\section{1.まえがき}

溶接継手汇用いられる溶接の種類は，(1)融接，(2) 壬接および（3）万う付に大別され，（1）には最む広 く使用されているアーク溶接,ガス溶接, テルミット溶 接, エレクトロスラグ溶接, 電子楾溶接などが含まれ,

（2）にはガス圧接, 抗抵溶接, 鍛接, 冷間圧接, 超音 波溶接などが含まれ，また（3）は硬ろう付と軟ろう付 などに分けられる，てれらの溶接はさらに溶接前後の溶 接部の形状などから，たとえばア一ク扔よびガス溶接で はグルーブ溶接, すみ肉溶接, プラグ溶接, ビード溶接 などに分けられ，抗抵溶接では点溶接，プロジェクショ ン溶接, シーム溶接, フラッシュ溶接, アプセット溶接 などに分けられる．このように溶接部の種類から分類す ると、テルミット溶接やエレクトロスラグ溶接も主とし てグルーブ溶接で使用されることが多い。これら溶接あ るいは溶接部の種類之継手の種類（突合せ継手，当て金 継手，重ね継手，T継手，功継手，ヘリ継手など）之 の組合せによって種々の溶接継手が構成される。

これらの溶接継手のうち, 重要構造物に使用されるの は主としてグルーブ溶接，およびすみ肉溶接の継手であ り，てれらは溶接継手の設計あるいは強度計算が他の溶 接継手に比較してとくに重要である.グルーブ溶接は強 度計算（静的）の必要は此較的少ないが，グルーブ形状 寸法の設計が重要であり，すみ肉溶接は他の溶接に比較 して強度計算をとくに必要とする。

\footnotetext{
* 原稿受付 昭和47年11月30日

** 正 第 鉄道技術研究所溶接研究案 Member, Railway Technical Research Institute of $J . N$.
}

溶接発達の初期においては, 施工の容易なすみ肉溶接 が好んで用いられたが，すみ肉溶接はルートに溶接欠陥 を生じやすく、ルートに切欠きを有し，また止端では断 面が急変するため，それらの部分の応力集中が大きくな り, 疲労強度が低いため繰返し応力の高いところや重要 個所には極力避けられ、グルーブ溶接継手を用いるのが 普通である.しかしてれらの久宿も静的強度にはあまり 影響しないととがわかっている。

本稿は上述の溶接継手の種類が痏学強度から見てどの 様に分類され，そしてそれらに対応する波労強度がどの 程度のむのであるか，また疲労設計上重要な疲労強度線 図の表わし万などについて述べる.なおデータについて は鋼に限ることにする。

\section{2. 構 造 種 別}

棈造物の疲労破壞は主として構造各部の応力集中によ るもので，ボルトあるいはびよう孔．溶接のような構造 的不連続および局部的あるいは全体的な幾何学的形状の 変化はすべてその主要因となるものである，てれには応 力条件の外飞, 継手の種類, 形状, 材料, 施工条件 (仕 上げ条件を含む），環境などが関連している.

波労荷重をうける構造各部の種類は, 各種締結法の場 合, 例えば溶接継手の種類をも含めて構造種別 (constructional details) と称しているが，てれには綂結法に よる種類例えば溶接の種類と継手の種類の組合せによる 溶接継手の種類形状の外に，継手上荷重（種類捛よび力 向）之の関係が加味されている。例えば「横緑」とは部

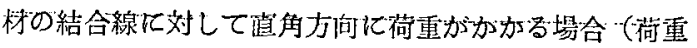

